\title{
A method of strengthening arched buildings with insufficient bearing capacity of foundations for the thrust perception
}

\author{
Damir Khusainov ${ }^{1}$, Ivan Kuznetsov ${ }^{10000-0001-6838-0319]}$, and Albina Khabibulina ${ }^{1 *}$ [0000-0003-2928- \\ 2884]
}

${ }^{1}$ Kazan State University of Architecture and Engineering, 420043, Zelenaya st., Kazan, Russia

\begin{abstract}
This paper proposes a new way to strengthen arched buildings with an insufficient bearing capacity of the foundations for the thrust perception. The new method of strengthening the arched buildings can be used in architectural and structural solutions of buildings with zones where it is impossible to place tie-beams traditionally. In the literature there are no research results on this issue. The authors described a new method of strengthening arched buildings. Using a frameless arched structure with an insufficient bearing capacity of the foundations for the thrust as an example, they considered the proposed strengthening method with two options for anchoring the arched building's foundation with tie-beams installed to perceive the thrust to semi-buried and buried anchors. The authors carried out theoretical studies and determined the magnitude of the prestresses in the installed tie-beams to ensure the bearing capacity of the arched building for the variant of asymmetric snow design load. Conclusions. The significance of the obtained results for the construction industry is to propose a method to strengthen arched structures with an insufficient bearing capacity of the foundations for the thrust perception. The proposed method of strengthening is an effective and novel way of increasing the bearing capacity of structures and foundations of arched buildings and can be used in architectural and structural solutions of buildings with zones that impede the traditional placement of tie-beams.
\end{abstract}

Keywords: arched building, thrust, support, tightening, anchor, frameless arched building, prestressing.

\section{Introduction}

The arched structure is one of the widespread structural systems in construction. The range of its application is wide. It includes small buildings of agricultural enterprises, small business and large-span buildings for sports or public purposes [1-5]. Distinctive features of arched buildings are the ability of quick erection, a small mass of structures, low construction costs and the need to take into account the impact of thrust support reactions when designing the foundations of arched buildings [6-10]. The problem of perceiving

${ }^{*}$ Corresponding author: albgomer@mail.ru 
thrust structures and reducing the material consumption for the foundation construction in arched buildings constructors solve by installing tie-beams between the arches' supports [11-15]. Builders face some problems when installing the tie-beams in arched structures: the need for their hidden installation in the construction of the floors; the necessity to prestress them to maintain a working condition at large spans; the impossibility of standard installation of tie-beams between the arch supports when utility lines of technological objects of the building located between the arch supports. Therefore, arched buildings with large spans are often designed without the tie-beams [16-20], which leads to insufficient bearing capacity of their foundations due to errors made in the design or due to deviations from design decisions. For arched buildings with an insufficient bearing capacity of foundations, the use of tie-beams to strengthen them is one of the most effective methods but complicated to implement. In this paper, the authors have considered methods of the arched structures reinforcement with unconventional technics of tie-beams installing. The use of special anchor devices allows solving the problems of their installation.

\section{Materials and methods}

In buildings, arched structures are widely used as a coating, where the tie-beams located above the premises of the buildings are an obligatory element that percept the thrust. With large spans of coatings, usually applied antisag bars connecting the arches of the coating and tightening. Where in tie-beams with antisag bars above the building operational areas «do not prevent» the exploitation of the building.

For example, it is necessary to erect arched buildings with the arch rests directly on the foundation, and at the same time, it is the combination of the arched fence as a wall and coating. In this case, the tie-beams for large span buildings are not a simple engineering problem that must be solved when designing a building. These tasks include the need to use tie-beams without antisag bars for large spans of arches, ensuring the tie-beams' durability, which must be placed below floor level. One of the ways to include large length tie-beams in work is their prestressing. To ensure the working condition of the tie-beams it was necessary to make technological channels between the supports of each arch in the building floor. Frequently, these engineering challenges face many constraints. For example, it is necessary to lay technological objects inside a building, having dimensions below the floor level and excluding the placement of tie-beams between the supports of the frame arches. The absence of tie-beams between arches always leads to overspending of materials for the construction of building foundations. For some light arched buildings, for example, frameless ones [21, 22], made of profiled sheeting, combining both enclosing and bearing functions, the use of tie-beams is one of the prerequisites for the possibility of their use with sufficiently large spans in areas with significant snow load. Scientists of Kazan state university of architecture and engineering (KSUAE) proposed structural solutions (see Figs. 1-3). It is an arched building, including arches supported on each side in the ground on opposite foundations. Between them, there are rod tie-beams that enclose structures along the arches. In this case, tie-beams made as rod elements connect each foundation with semiburied and buried anchors, located inside the building, namely, near the foundation on each side of the building.

The novelty of the proposed design solutions for arches with supports with anchor tiebeams (Figs. 1-3) is confirmed by the patent of Russian Federation 2019 No. 2725375. 


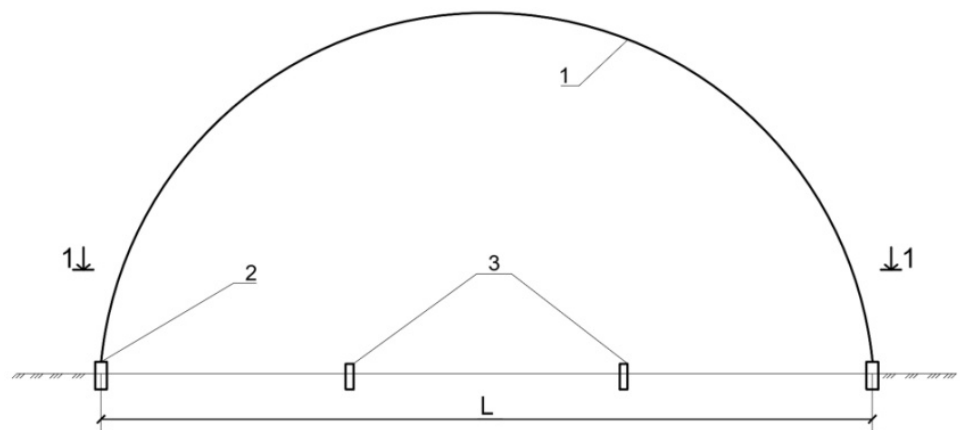

(A)

(B)

Fig. 1. Cross section of an arched building 1 with a span $L$ with supports 2 and anchoring devices 3 , half-buried in the floor of an arched building.

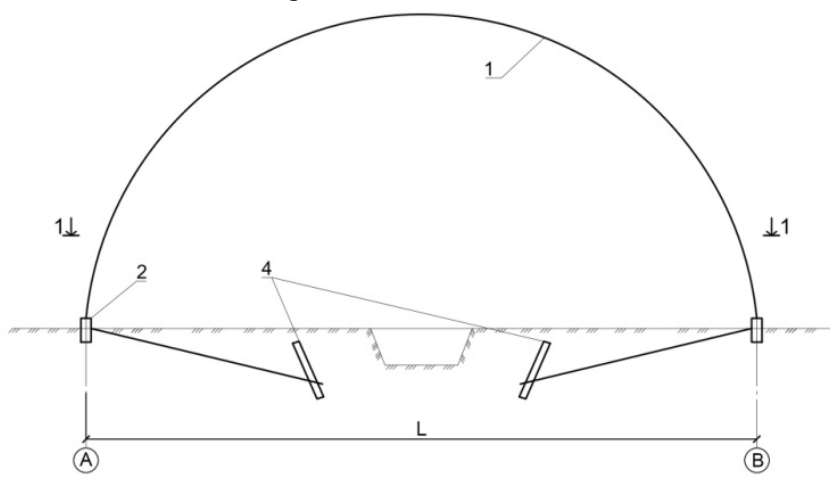

Fig. 2. Cross section of an arched building 1 with span $L$ with supports 2 and buried anchor devices in the form of anchors 4 .
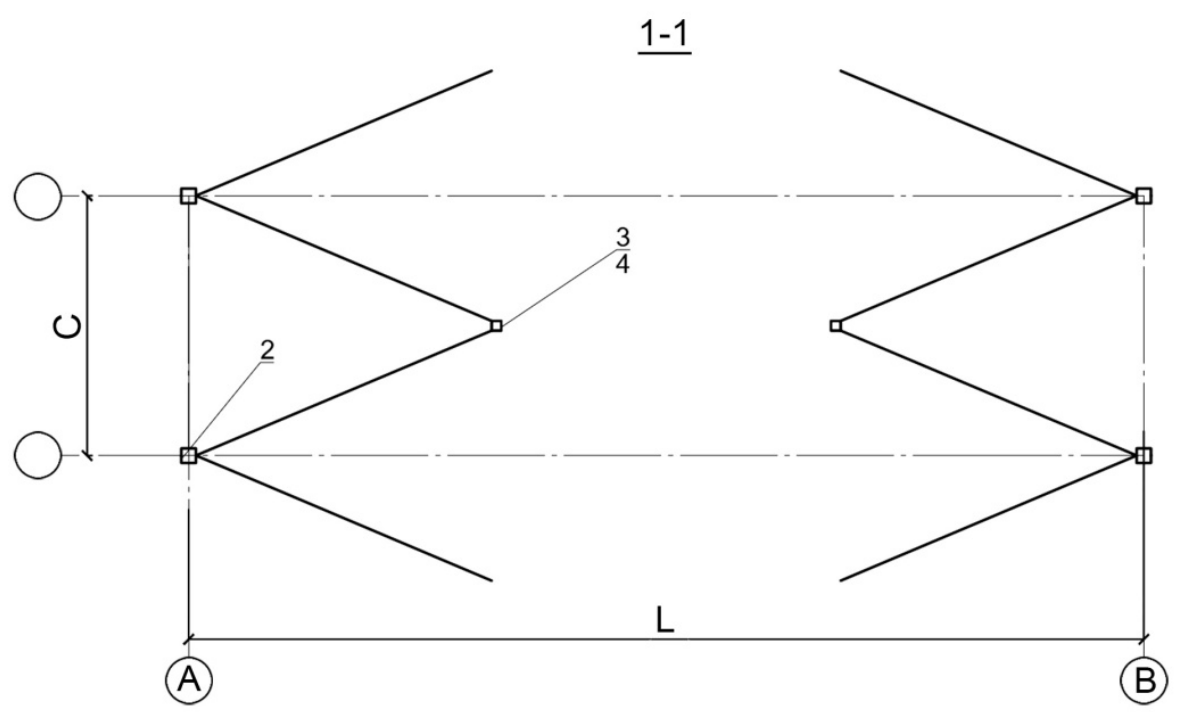

Fig. 3. Location of anchor devices in the form of half-buried anchors 3 or buried anchors 4 between the arches in the plan of the building and the supports 2. 


\section{Results and discussion}

The proposed constructive solutions for the device of arches supports with their fastening to the anchors are convenient to use when strengthening arched buildings. Let us consider the possibility of using the proposed design solutions when strengthening arched buildings using the example of an arched building built in Kazan (Republic of Tatarstan, Russia).

The arched hangar was built in 2018. The building is $72 \mathrm{~m}$ long, with a span of $21 \mathrm{~m}$. The hangar is designed for an estimated snow load of $240 \mathrm{~kg} / \mathrm{m}^{2}$. The hangar is single-span, frameless. The material of the supporting structures of the coating is steel $08 \mathrm{ps}$ GOST 14918-80. Constructive and design solutions of the arched building are shown in Figs. 4-6.

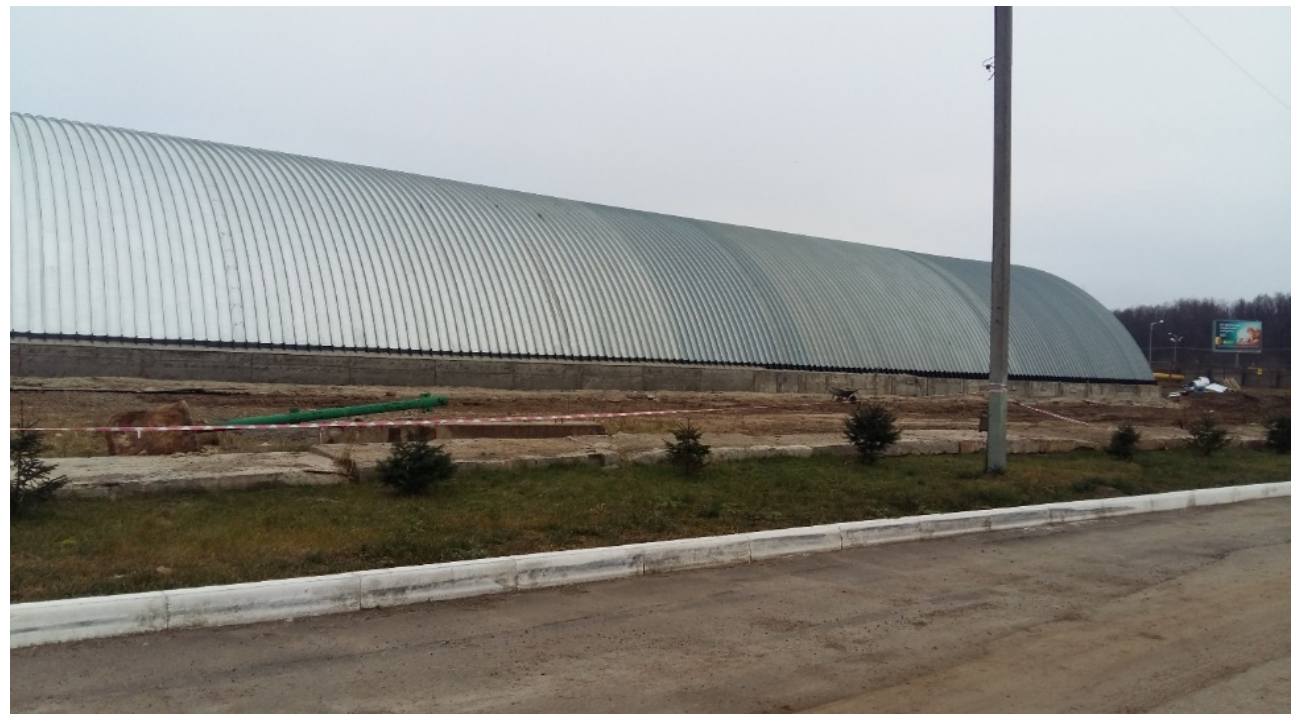

Fig. 4. Frameless arched hangar with a span of $21 \mathrm{~m}$ in Kazan.

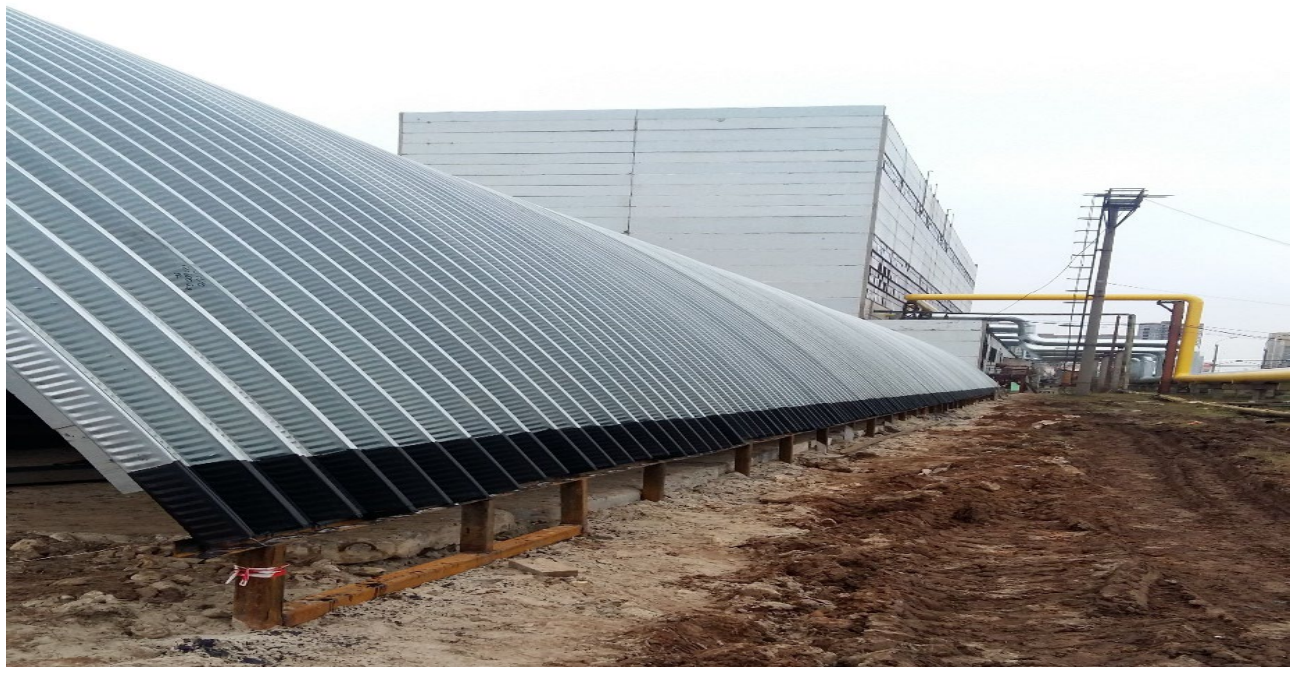

Fig. 5. Anchoring pillar with a section of a square pipe $80 \times 80 \times 5 \mathrm{~mm}$ with a step of $1.9 \mathrm{~m}$. 


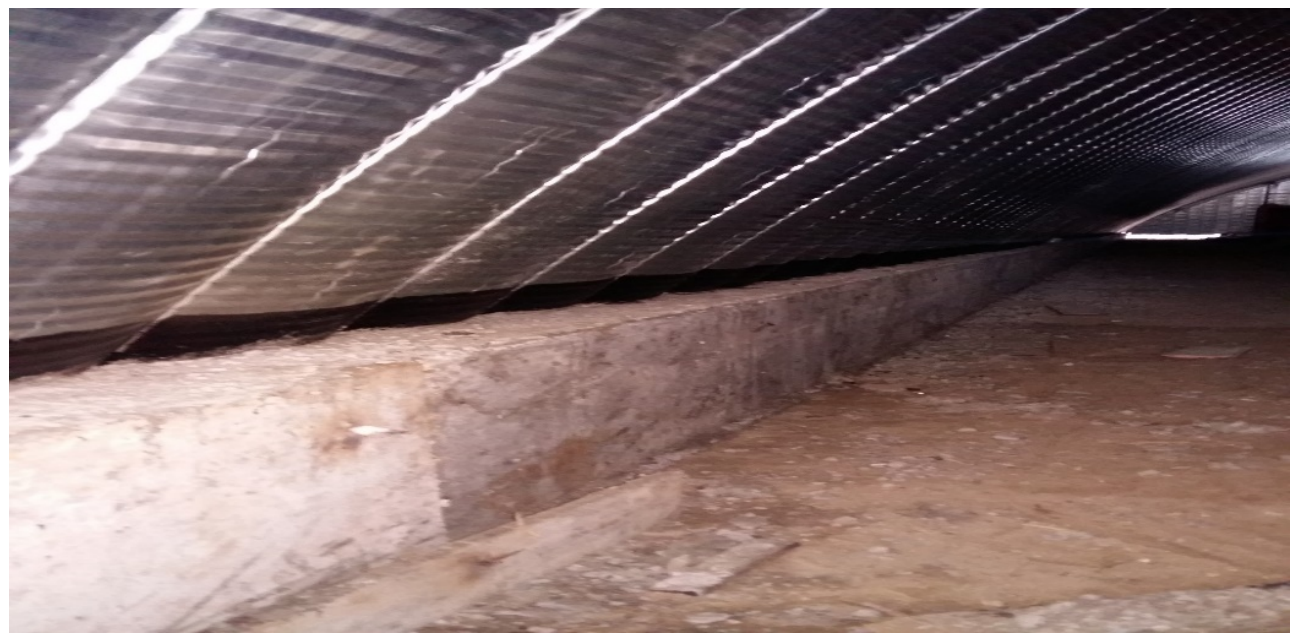

Fig. 6. Capping beam of the building foundation with a height of $0.5 \mathrm{~m}$.

Let us check the bearing capacity of the foundation of an arched building for the effect of the thrust value arising from the action of the calculated combination of loads, consisting of snow and constant loads.

Let's check the strength of the anchoring elements of the building foundation in piles from a square pipe $80 \times 80 \times 5 \mathrm{~mm}$, installed with a step of $1.9 \mathrm{~m}$.

The moment from the thrust in the element according to the results of calculations is $\mathrm{M}=1.62 \mathrm{tm}$.

The strength check for steel material of C245 class is performed according to the formula:

$$
\mathrm{M} / \mathrm{W}_{\mathrm{x}}=162000 / 35.3=4589 \mathrm{~kg} / \mathrm{cm}^{2} \geq \mathrm{R}_{\mathrm{y}} \gamma \mathrm{c}=2400 \mathrm{~kg} / \mathrm{cm}^{2}
$$

where $\mathrm{W}_{\mathrm{x}}=35.3 \mathrm{~cm}^{3}$ is the resistance moment of a square pipe

Conclusion: the strength of the anchor elements of the foundation is not sufficient to perceive the thrust design value from the design load.

The coefficient of use of the cross-section of the anchoring pillars of the piles of capping beam is $\mathrm{Ki}=4306 / 2400=1.79$

To strengthen the capping beam for this arched building, the authors developed methods for strengthening the foundations using tie-beams with anchors: method 1 (Fig. 7) and method 2 (Fig. 8). 

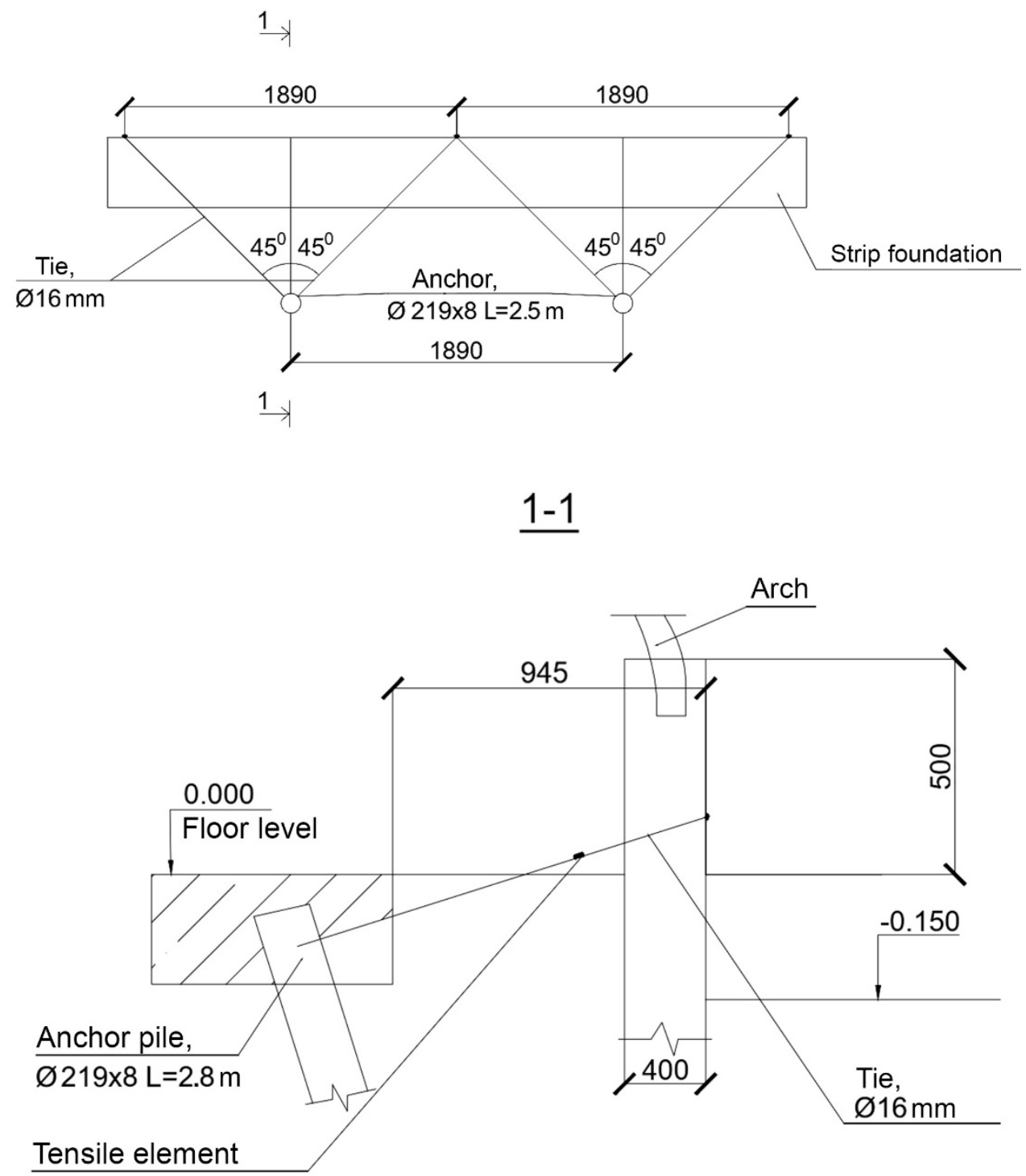

Fig. 7. Method 1. Installation of tie-beams in the strip foundation of an arched building with steel pile anchors.

Tie-beam anchors in this method are made of pipes with a section of $\varnothing 219 \times 8 \mathrm{~mm}$, which are driven into the ground by $2.5 \mathrm{~m}$ and are located along the strip foundation and their pitch is determined by the anchoring capacity of the pile anchor. 

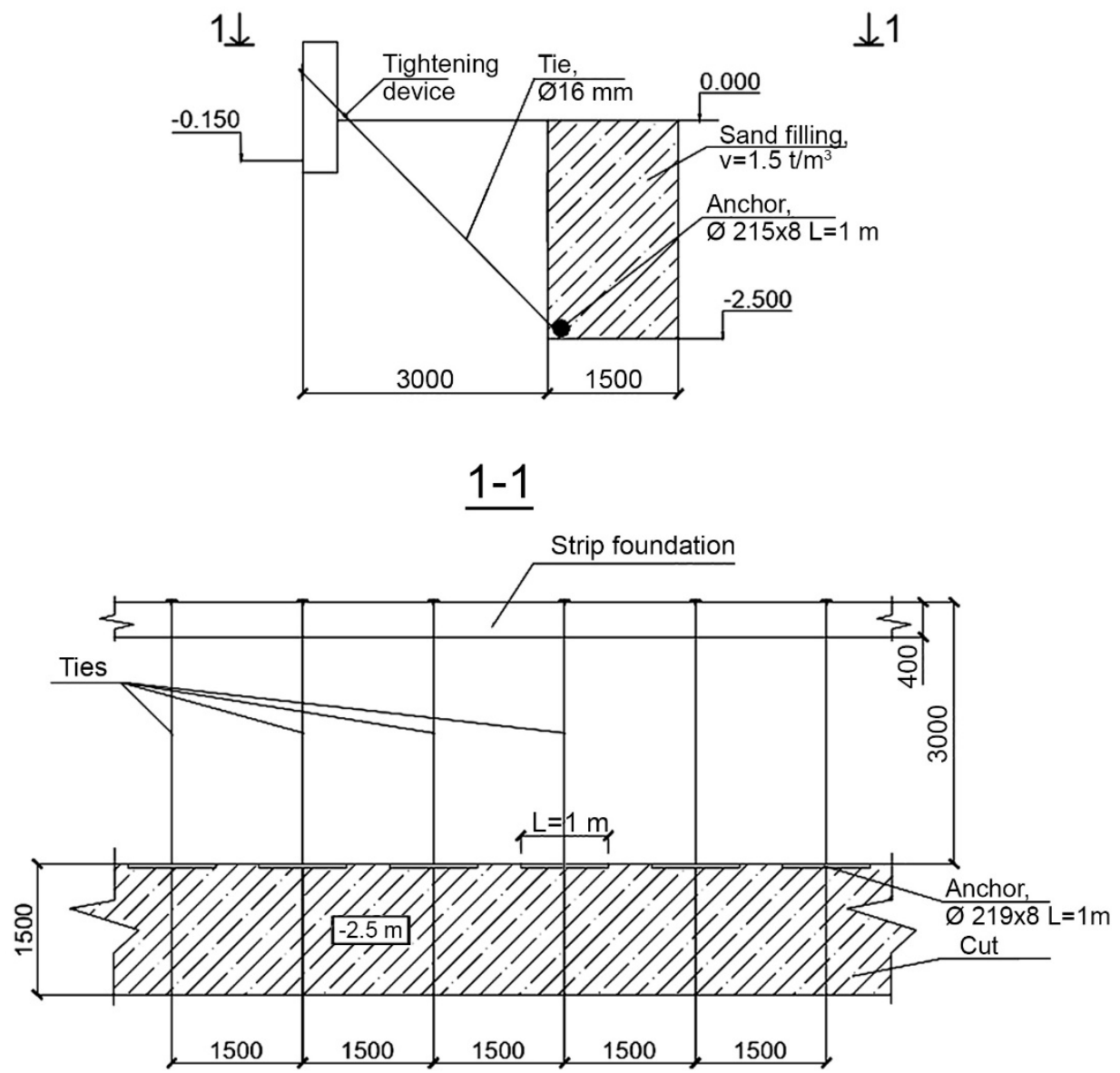

Fig. 8. Method 2. Installation of tie-beams in the strip foundation of an arched building with steel pile anchors.

Tie-beams in this method of anchoring are installed with a step of $1.5 \mathrm{~m}$ with anchoring to recessed anchors $1 \mathrm{~m}$ long from a pipe with a cross-section $\varnothing 219 \times 8 \mathrm{~mm}$. Anchors are placed in a previously dug trench of $1.5 \mathrm{~m}$ wide and $2.5 \mathrm{~m}$ deep. After the anchors are installed, the trench is filled with sand with a bulk density of at least $1.5 \mathrm{t} / \mathrm{m}^{3}$.

The use of anchor tie-beams in arched buildings is also possible when it is necessary to strengthen the load-bearing elements of arched buildings by changing their design schemes by prestressing the installed tie-beam.

Let us consider the possibility of strengthening the considered arched frameless building, which does not have sufficient bearing capacity.

Let us consider the calculation of the supporting structures of an arched building for design loads, including a snow load of $240 \mathrm{~kg} / \mathrm{m}^{2}$ (design snow load for Kazan in 20172018).

The geometric characteristics of the profile of a frameless building were determined based on the results of actual measurements. The main element of the arch is a cold-formed profile made of galvanized steel sheet $1.2 \mathrm{~mm}$ thick, $123 \mathrm{~mm}$ high. Profile material is steel 08ps GOST 14918-80 according to the data provided by the owner of the building. 
The bearing capacity of an arched coating made of a cold-formed profile in a design section for a design combination of loads, including a constant load and a snow load with its location on both sides of the building span, is determined by the combined action of the axial force and bending moment by the formula:

$$
\mathrm{N} / \mathrm{A}+\mathrm{M} / \mathrm{Wy}=9800 / 14.31+78900 / 58.6=2031 \mathrm{~kg} / \mathrm{cm}^{2} \leq \mathrm{Ry} \gamma \mathrm{c}=2300 \mathrm{~kg} / \mathrm{cm}^{2}
$$

where $\mathrm{A}=14.31 \mathrm{~cm}^{2}$ and $\mathrm{W}_{\mathrm{y}}=586 \mathrm{~cm}^{3}$ respectively, the cross-sectional area and the moment of resistance of the net of a strip of an arched coating with a width of $0.6 \mathrm{~m}$, $\mathrm{R}_{\mathrm{y}}=2300 \mathrm{~kg} / \mathrm{cm}^{2}$ - design resistance at yield point 08ps according to GOST 14918-80, $\mathrm{N}, \mathrm{M}-$ axial force and moment in the design section of the arched coating.

Conclusion: The load-bearing capacity of the arched coating at the given design combination of loads is provided.

The bearing capacity of an arched coating made of a cold-formed profile in a design section for a design combination of loads, including a constant load and a snow load with its one-sided location on the span of a building, is determined by the combined action of axial force and bending moment by the formula:

$$
\mathrm{N} / \mathrm{A}+\mathrm{M} / \mathrm{Wy}=6500 / 14.31+129000 / 58.6=2655 \mathrm{~kg} / \mathrm{cm}^{2}>\mathrm{Ry} \gamma \mathrm{c}=2300 \mathrm{~kg} / \mathrm{cm}^{2}
$$

where $\mathrm{A}=14.31 \mathrm{~cm}^{2}$ and $\mathrm{Wy}=586 \mathrm{~cm}^{3}$, respectively, the cross-sectional area and the moment of resistance of the net of the strip of the arched coating with a width of $0.6 \mathrm{~m}$, $\mathrm{Ry}=2300 \mathrm{~kg} / \mathrm{cm}^{2}-$ design resistance at yield point $08 \mathrm{ps}$ according to GOST $14918-80$, $\mathrm{N}, \mathrm{M}-$ axial force and moment in the design section of the arched coating.

Conclusion: with the calculated combination of loads, when the snow is located only on one side of the building span, the bearing capacity of the building is not ensured.

When designing an arched frameless building, the possibility of locating the calculated snow load on only one side of the span was not considered and, accordingly, the insufficient bearing capacity of the arched building was not revealed.

Let us consider the possibility of using prestressed tie-beams to reinforce the arched coating. Authors provide the application of tie-beams with anchorage to buried anchors (Fig. 7 and Fig. 8).

Let us consider the design scheme of an arched coating with tie-beams, with fastening them to the anchors and setting a pre-tension in them.

Based on the results of the numerical studies for the selected design scheme of the arched coating, it was found that the optimal distribution of the design bending moments is achieved when the prestressing force of the installed tie-beams of the arched coating is 440 $\mathrm{kg}$.

The bearing capacity of the arched cover made of a cold-formed profile in the design section (for PCN2) is determined by the combined action of the axial force and bending moment according to the formula:

$$
\mathrm{N} / \mathrm{A}+\mathrm{M} / \mathrm{W}_{\mathrm{y}}=840 / 14.31+125336 / 58.6=2197 \mathrm{~kg} / \mathrm{cm}<\mathrm{R}_{\mathrm{y}} \gamma \mathrm{c}=2300 \mathrm{~kg} / \mathrm{cm}^{2}
$$

where $\mathrm{A}=14.31 \mathrm{~cm}^{2}$ and $\mathrm{W}_{\mathrm{y}}=586 \mathrm{~cm}^{3}$, respectively, the cross-sectional area and the moment of resistance of the net of a strip of an arched coating with a width of $0.6 \mathrm{~m}$, $\mathrm{R}_{\mathrm{y}}=2300 \mathrm{~kg} / \mathrm{cm}^{2}$ - design resistance at yield point $08 \mathrm{ps}$ according to GOST $14918-80$, $\mathrm{N}, \mathrm{M}-$ axial force and moment in the design section of the arched coating.

Conclusion: with the calculated combination of loads, when the snow is located only on one side of the building span, the bearing capacity of the building with the prestressing force in the tie-beams with its fastening to the anchors of $440 \mathrm{~kg}$ is provided.

This example of the use of anchor tie-beams to strengthen the structures of arched buildings shows one of the methods of application of the proposed tie-beams of arched buildings with their fastening to anchors. For the considered implemented arched building, 
which has insufficient bearing capacity due to design errors, the installation of reinforcing tie-beams for the supports of the arched coating according to the schemes shown in Fig. 7 or Fig. 8 may be the best method for strengthening an arched building.

\section{Conclusions}

Based on the studies, we can conclude that the use of tie-beams for the supports of arched buildings, with their fastening on one side to the supports and on the other side to anchors, is an effective, novel way. Due to this method the bearing capacity of coating increases, and foundations of arched buildings in terms of architectural and structural solutions with the presence of zones that impede the traditional placement of tie-beams.

\section{References}

1. M. R. Sheidaii, S. Bayrami, M. Babaei, International Journal of Steel Structures, 13(4), 723-730 (2013) DOI: 10.1007/s13296-013-4013-y

2. Kyoungsoo Lee, Sang-Eul Han, Journal of Constructional Steel Research, 92, 195-210 (2014) DOI: 10.1016/j.jcsr.2013.09.011

3. S. Karimi, J Fundam Appl Sci., 9(1S), 573-596 (2017) DOI: 10.4314/jfas.v9i1s.713

4. F. Flager, G. Soremekun, A. Adya, K. Shea, J. Haymaker, M. Fischer, Computers and Structures, 140, 55-65 (2014) DOI: 10.1016/j.compstruc.2014.05.002

5. M. Dallemule, Slovak Journal of Civil Engineering, 23(3), 9-15 (2015) DOI: 10.1515/sjce-2015-0012

6. P. P. Nomikos, A. I. Sofianos, K. M. Sakkas, D. Choumanidis, S. Delendas, Tunnelling and Underground Space Technology, 38, 180-188 (2013) DOI: 10.1016/j.tust.2013.06.006

7. A. A. Kalinina, A. I. Kurbanov, N. G. Tsaritova, IOP Conf. Ser.: Mater. Sci. Eng., 1079, 042041 (2021) DOI: 10.1088/1757-899X/1079/4/042041

8. Jwo-Hua Chen, Applied Mechanics and Materials, 121-126, 3113-3117 (2012) DOI: 10.4028/www.scientific.net/AMM.121-126.3113

9. S. Afshana, M. Theofanousb, J. Wangc, M. Gkantoud, L. Gardner, Engineering Structure, 183, 510-522 (2019) DOI: 10.1016/j.engstruct.2019.01.007

10. P. P. Gaydzhurov, E. R. Iskhakova, N. G. Tsaritova, International Journal for Computational Civil and Structural Engineering, 16(1), 38-47 (2020) DOI: 10.22337/2587-9618-2020-16-1-38-47

11. W. Sun, W. Zhou, Applied Mechanics and Materials 271-272, 519-523 (2012) DOI: 10.4028/www.scientific.net/AMM.271-272.519

12. V. S. Pantazia, D. S. Sophianopoulos, Special Issue: Proceedings of Eurosteel 2017 1(23), 1399-1406 (2017). DOI: 10.1002/cepa.182

13. F. N. Gimena, P. Gonzaga, L. Gimena, Engineering Structures, 60, 189-198 (2014). DOI: $10.1016 /$ j.engstruct.2013.12.004

14. S. Castellano, Journal of Agricultural Engineering, 38(1), 21-29 (2007) DOI: 10.4081/jae.2007.1.21

15. U. Eroglu, A. Paolone, G. Ruta, Arch Appl Mech, 90, 673-689 (2020) DOI: 10.1007/s00419-019-01633-x

16. M. Wells, Civil Engineering, 168(1), 19-24 (2015) DOI: 10.1680/cien.14.00044

17. V. Rybakov, V. Jos, I. Raimova, K. Kudryavtsev, IOP Conf. Ser.: Mater. Sci. Eng., 883, 012197 (2020). DOI: 10.1088/1757-899X/883/1/012197

18. Qi Xia Liu, Yang Zhao, Applied Mechanics and Materials, 204-208, 1034-1039 (2012) DOI: 10.4028/www.scientific.net/AMM.204-208.1034

19. A. Z. Kamalov, A. A. Khamidullina, Izvestiya KGASU, 4(22), 130-138 (2012) 
20. Lingyao Li, Shichang He, Xuhui He, Haiquan Jing, Advances in Structural Engineering, 23(12), 2614-2625 (2020) DOI: 10.1177/1369433220916935

21. V. M. Bezsalyi, D. O. Bannikov, Bridges and tunnels. Theory Research Practice, 16, 20-29 (2019) DOI: 10.15802/bttrp2019/189428

22. I. L. Kuznetsov, A. V. Isaev, L. R. Gimranov, Izvestija KGASU, 4(18), 166-170 (2011) 